\title{
Mechanical properties and resistance to fungi and termite in particleboard of eucalyptus
}

\section{Propiedades mecánicas y resistencia a hongos y termitas en tableros de eucalipto}

\section{Vinicius Peixoto Tintil, Fabricio Gomes Gonçalves ${ }^{*}$, Juarez Benigno Paes!' Marina Donária Chaves Arantes² and Michel Cardoso Vieira ${ }^{3}$}

\footnotetext{
Federal University of Espírito Santo, Department of Forest and Wood Science, Jerônimo Monteiro, ES, Brazil.

2 Federal University of São João Del-Rei, Department of Agrarian Sciences, Sete Lagoas, MG, Brazil.

* Corresponding author. fabricio.goncalves@ufes.br

3 Federal Rural University of Rio de Janeiro, Department of Forest Products, Seropédica, RJ, Brazil.
}

\begin{abstract}
The objective of this study was to evaluate the mechanical resistance and resistance to degrading agents in particleboard with eucalyptus wood residue and Urea-Formaldehyde, Phenol-Formaldehyde and Tannin-Formaldehyde adhesives at two temperatures $\left(120{ }^{\circ} \mathrm{C}\right.$ and 140 $\left.{ }^{\circ} \mathrm{C}\right)$. The panels were produced in the dimensions of $40 \mathrm{~cm} \times 40 \mathrm{~cm} \times 1.25 \mathrm{~cm}$ (width, length and thickness, respectively); $10 \%$ and $20 \%$ of tannin (50\% solution) was added to the pure adhesives. The following parameters were evaluated: Modulus of Rupture (MOR) and Modulus of Elasticity (MOE) in static bending, internal bonding, screw withdrawal, resistance to rotting fungi and dry wood termite. MOR showed better results at $120^{\circ} \mathrm{C}$. None of the treatments reached the minimum standard for the MOE, contrary to the internal bonding. The Trametes versicolor fungus caused greater mass loss to the tested panels when compared to Postia placenta. The proportion of tannin (90:10) in the phenolic adhesive contributed to a decrease in the resistance of the panel to the dry wood termite.
\end{abstract}

KEYWORDS: biodeterioration, lignocellulosic residue, panel quality, panels.

\section{RESUMEN}

El objetivo de este estudio fue evaluar la resistencia mecánica y la resistencia a agentes degradadores en tableros de partículas con madera de eucalipto con adhesivos a base de urea-formaldehído, phenol-formaldehído y tanino-formaldehído a dos temperaturas $\left(120{ }^{\circ} \mathrm{C}\right.$ y 140 ${ }^{\circ} \mathrm{C}$ ). Las dimensiones de los tableros fueron $40 \mathrm{~cm} \times 40 \mathrm{~cm} \times 1.25 \mathrm{~cm}$ (ancho, largo y grosor, respectivamente); se agregó $10 \%$ y $20 \%$ de taninos (solución al 50\%) a los adhesivos puros. Los parámetros evaluados fueron: módulo de ruptura (MOR), módulo de elasticidad en flexión estática (MOE), cohesión interna, extracción de clavos, resistencia a descomposición por hongos y a termitas de madera seca. El hongo Trametes versicolor causó mayor pérdida de masa a los tableros ensayados en comparación con la causada por Postia placenta. La proporción de taninos (90:10) en el adhesivo fenólico contribuyó a disminuir la resistencia del tablero al ataque de termitas de madera seca.

PALABRAS CLAVE: biodeterioro, residuo lignocelulosico, calidad del tablero, tableros.

\section{INTRODUCTION}

Agglomerated panel is a technical term for panels produced with pure wood particles (with standard size) or with the addition of other lignocellulosic materials, bonded with synthetic or natural adhesive in the presence of heat, pressure and temperature (Iwakiri, Keinert Júnior, \& Mendes, 2005; Maloney, 1996; Pizzi, 1994b).

The adhesive is an important component, with significant technical and economic implications in the use of wood products (Pizzi, 1994a), costing 50\% of the total 
final product price (Carneiro, Vital, Pimenta, and Della Lucia, 2004). According to Kollmann, Kuenzi and Stamm (1975), wood adhesives are classified as naturally occurring (casein, leather, bone, blood and soy); synthetic thermosets (urea, phenol, melamine, resorcinol, tannin and epoxy), which are converted to an irreversible, insoluble state by means of chemical reactions with or without the application of heat; and synthetic thermoplastics (polyvinyl chloride PVC, polyvinyl acetate - PVA and elastomers), which resist only physical changes, changing by the action of heat or solvent evaporation.

Synthetic adhesives are the most used adhesives in the production of agglomerated panels, among them ureaformaldehyde and phenol-formaldehyde. The first one is preferred by the particleboard industries for indoor use due to its low cost and shortest reaction time in hot pressing, and for having a clear line of glue and easy workability (Albuquerque, Iwakiri, \& Keinert Junior, 2005; Maloney, 1993), hardness, nonflammability and solubility in water (Pizzi, 1994b). The disadvantages of urea-formaldehyde are its low resistance to humidity and the easy release of formaldehyde, which can lead to health problems. The addition of phenol, melamine or tannin, are alternatives to improve dimensional stability; and the consequent reduction of formaldehyde to the environment, which can be controlled by decreasing the proportion thereof in relation to the amount of urea used (Maloney, 1977; Pizzi, 1994b).

Tannins are natural substances produced by plants, with a protective function against attacks of biotic agents such as insects, microorganisms and other herbivores (Paes, Santana, Azevedo, Morais, \& Calixto Junior, 2010). The same authors affirmed that the tannins are distributed in different parts of the plants such as leaves, fruits, branches and trunks, with certain mobility in different times of the year, according to their physiology, varying in quantity according to the genus and species, thus giving greater or less resistance to attack by pathogens or pests.

Tannins, according to Pizzi (1980), can be used as substitutes for phenol or other synthetic compounds to produce adhesives, with satisfactory technological properties that meet the technical and normative specifications.

\section{OBJECTIVES}

Based on the above, the present work had the objective of evaluating the mechanical resistance and resistance to xylophagous organisms in agglomerated panels produced with eucalyptus wood residue and adhesives as the tannin base with urea formaldehyde and phenol foemaldehyde.

\section{MATERIALS AND METHODS}

The wood particles came from a sawmill located in the region of Caparaó, south of the state of Espírito Santo, Brazil, coming entirely from wood residue of Eucalyptus spp out of a wood processor. This residue was a mixture of bark and sawdust. The collected material was dried by air until reaching a humidity of approximately $15 \%$. After this stage, it was classified through a vibrating sieve, using those particles that passed the $4.0 \mathrm{~mm}$ mesh and were retained in the $2.0 \mathrm{~mm}$ mesh. The residue did not undergo any type of fragmentation and was oven dried at $103{ }^{\circ} \mathrm{C} \pm 2{ }^{\circ} \mathrm{C}$ until it reached the pre-established humidity of $5 \%$, and then stored in hermetically sealed plastic bags. In addition to the residues, samples of wood with dimensions of approximately $5 \mathrm{~cm} \times 5 \mathrm{~cm} \times 5 \mathrm{~cm}$ were collected to determine their specific mass (Associação Brasileira de Normas Técnicas [ABNT], 2003).

For each adhesive (Table 1) three panels were produced, with nominal density of $6.865 \mathrm{kN} \mathrm{m}^{-3}\left(700 \mathrm{~kg} \mathrm{~m}^{-3}\right)$ and compaction ratio of 1.25 , totaling 42 particleboards. The dried particles were taken to a spinning drum-type gluing machine for application of $10 \%$ adhesive (relative to dry particle mass). As catalysts, $24 \%$ ammonium sulfate, $60 \%$ potassium carbonate and 37\% formaldehyde were used in the proportions of $2 \%, 6 \%$ and $20 \%$ on the solids content of the urea, phenol and tannin adhesives, respectively.

The glued particles were deposited in a shaping box with dimensions of $42.5 \mathrm{~cm} \times 42.5 \mathrm{~cm}$ and pre-cold pressed forming a mattress; the hot-pressing cycle was then applied at two temperatures $\left(120^{\circ} \mathrm{C}\right.$ and $\left.140{ }^{\circ} \mathrm{C}\right)$ at a specific 
TABLE 1. Composition of the adhesives studied.

\begin{tabular}{ccc}
\hline Adhesives & Adhesives Composition & Temperature $\left({ }^{\circ} \mathrm{C}\right)$ \\
\hline UF & $100 \%$ Urea-formaldehyde & \\
\hline PF & $100 \%$ Phenol-formaldehyde & \\
\hline TF & $100 \%$ Tannin-formaldehyde & 120 and 140 \\
\hline TUF 90:10 & $90 \%$ Urea-formaldehyde $+10 \%$ tannin & \\
\hline TUF 80:20 & $80 \%$ Urea-formaldehyde $+20 \%$ tannin & \\
\hline TPF 90:10 & $90 \%$ Phenol-formaldehyde $+10 \%$ tannin & \\
\hline TPF 80:20 & $80 \%$ Phenol-formaldehyde $+20 \%$ tannin \\
\hline
\end{tabular}

pressure of $3.92 \mathrm{MPa}\left(40 \mathrm{kgf} \mathrm{cm}^{-2}\right)$ for a period of 8 minutes. After pressing and cooling, the panels were squared, obtaining the final dimension of $40 \mathrm{~cm} \mathrm{x} 40 \mathrm{~cm} \times 1.25 \mathrm{~cm}$, and stored in an air-conditioned room $(65 \% \pm 5 \%$ humidity and $20^{\circ} \mathrm{C} \pm 2{ }^{\circ} \mathrm{C}$ ) until stabilization (ABNT, 2006).

After the air conditioning, samples were taken to perform the mechanical tests, which followed the normative recommendations for specific mass, internal bonding, static bending (modulus of elasticity - MOE, and rupture - MOR), screw withdrawal - surface and top (ABNT, 2006). The average values of $\mathrm{pH}$, viscosity and solids content of the used adhesives are shown in table 2 .

The test for biodeterioration resistance to brown rot (Postia placenta) and white rot fungi (Trametes versicolor), in which mass loss was evaluated (resistance class), was carried out according to the standard ASTM D-1413 (American Society for Testing and Materials [ASTM] 2005a) and ASTM D-2017 (ASTM, 2005b) (Table 3).

In order to verify the resistance of the agglomerated panels to the dry wood termite (Cryptotermes brevis), a modification was used in the analysis proposed by the Institute of Technological Research / Wood Division - IPT / DIMAD D-2 (1980). At the end of the test, the specimens were evaluated for termite mortality and mass loss, the latter, in percentage, was transformed by the expression Arcsen $(\sqrt{ }(\mathrm{x} / \mathrm{100}))$. No grades were awarded because surface wear had occurred imperceptibly.

The effect of the adhesives was verified by applying the analysis of variance and, for its validation, the Kolmogorov-Smirnov test was used to verify the normality of the data (Silva \& Azevedo, 2002). The statistical design was the completely randomized in factorial scheme $(2 \times 7)$, with the temperature in two levels and the adhesive in 7 levels, proceeding with the analysis of variance for all the tests. In the case of statistical difference, the Tukey test ( $p$ $\leq 0.05)$ was applied.

\section{RESULTS AND DISCUSSION}

\section{Mechanical Properties}

The mean values of modulus of rupture (MOR) ranged from 1.28 $\mathrm{MPa}$ to $7.35 \mathrm{MPa}$. The adhesive that presented the lowest values was TPF 80:20 (Table 4). According to CS 236-66 (Commercial Standard [CS], 1968), the minimum required value is $5.6 \mathrm{MPa}$; only three adhesives types reached this value which were UF and PF at $120{ }^{\circ} \mathrm{C}$ and UF at $140{ }^{\circ} \mathrm{C}$. This property, overall, showed best results at the temperature of $120^{\circ} \mathrm{C}$.

In the same table are the values for the modulus of elasticity (MOE), which ranged from 186.21 MPa to 931.71 $\mathrm{MPa}$. Again, the adhesive that presented the lowest value was the TPF 80:20. None of the adhesives tested for this property met the minimum value required by CS 236-66 (1968), which is $1050 \mathrm{MPa}$. The best value observed in this study for MOE was $100 \%$ UF adhesive at $120{ }^{\circ} \mathrm{C}(931.71 \mathrm{MPa})$, but still $11.27 \%$ below the established by the standard.

The temperature influenced the results on all adhesives used. The addition of tannin to urea-formaldehyde showed no statistical difference in the properties (MOR and MOE) at both temperatures; different behavior was observed for the addition of tannin to phenol-formaldehyde. 
TABLE 2. Values of $\mathrm{pH}$, viscosity and solids content of the adhesives.

\begin{tabular}{cccc}
\hline Adhesive & Ph & Viscosity (cP) & Solids content (\%) \\
\hline Urea-formaldehyde (UF) & 8.26 & $1,200.00$ & 70.50 \\
Phenol-formaldehyde (PF) & 13.77 & 616.20 & 52.89 \\
Tannin-formaldehyde (TF) & 3.52 & 580.00 & 46.51 \\
TUF* 90:10 & 5.14 & $1,024.10$ & 61.31 \\
TUF 80:20 & 4.20 & $1,490.88$ & 60.37 \\
TPF 90:10 & 12.84 & $1,375.27$ & 49.39 \\
TPF 80:20 & 12.28 & $6,739.00$ & 50.93 \\
\hline
\end{tabular}

*TUF: Tannin urea-formaldehyde; TPF: Tannin phenol-formaldehyde. Modified with tannic solution 50\%.

TABLE 3. Classes of resistance of wood degraded by rotting fungi.

\begin{tabular}{cc}
\hline Classes of Resistance & Average Mass Loss (\%) \\
\hline Highly resistant & $0-10$ \\
Resistant & $11-24$ \\
Moderately resistant & $25-44$ \\
Slightly resistant or non-resistant & $\geq 45$ \\
\hline
\end{tabular}

Source: ASTM D-2017 (2005b).

TABLE 4. Mean values of modulus of rupture - MOR and elasticity - MOE for adhesives and tested temperatures.

\begin{tabular}{|c|c|c|}
\hline \multirow[t]{2}{*}{ Adhesive } & \multicolumn{2}{|c|}{$\begin{array}{c}\text { MOR }(\mathrm{MPa}) \\
\text { Temperature }\left({ }^{\circ} \mathrm{C}\right)\end{array}$} \\
\hline & 120 & 140 \\
\hline UF $100 \%$ & $7.35(1.5) \mathrm{aA} *$ & 6.22 (1.1) bA \\
\hline PF 100\% & $6.33(1.4) \mathrm{aB}$ & $2.07(0.6) \mathrm{bD}$ \\
\hline TF 100\% & $4.81(0.8) \mathrm{aC}$ & $4.49(0.7) \mathrm{aB}$ \\
\hline TUF 90:10 & $4.55(1.2) \mathrm{aC}$ & 2.55 (1.5) bD \\
\hline TUF 80:20 & 5.15 (1.3) aC & 3.26 (1.0) bC \\
\hline TPF 90:10 & $3.42(0.6) \mathrm{aD}$ & $2.53(0.5) b D$ \\
\hline TPF 80:20 & $1.28(0.2) \mathrm{bE}$ & $4.69(0.9) \mathrm{aB}$ \\
\hline \multirow{2}{*}{ Adhesive } & \multicolumn{2}{|c|}{$\begin{array}{c}\text { MOE (MPa) } \\
\text { Temperature }\left({ }^{\circ} \mathrm{C}\right)\end{array}$} \\
\hline & 120 & 140 \\
\hline UF $100 \%$ & 931.71 (179.5) aA & 779.12 (115.6) bA \\
\hline PF 100\% & $829.61(160.7) a A B$ & 262.67 (62.6) bD \\
\hline TF 100\% & 770.09 (102.7) aBC & 584.61 (105.0) bB \\
\hline TUF 90:10 & 597.70 (158.2) aD & 349.23 (212.0) bCD \\
\hline TUF 80:20 & 661.69 (168.6) aCD & 463.36 (124.0) bBC \\
\hline TPF 90:10 & 453.47 (59.9) aE & 330.31 (68.9) bCD \\
\hline TPF 80:20 & 186.21 (30.9) bF & $597.71(109.5) \mathrm{aB}$ \\
\hline
\end{tabular}

* Means followed by lower case letter, in the line, and upper case in the column (for the respective property), do not differ statistically ( $p \leq 0.05$ ) by the Tukey test. Value in parentheses is the standard deviation. 
Gonçalves, Lelis and Oliveira (2008), when studying agglomerated panels of Eucalyptus urophylla at different levels of Acacia mearnsii tannin with urea-formaldehyde adhesive, found mean values for MOR of $13.53 \mathrm{MPa}(100 \% \mathrm{UF})$ and $12.94 \mathrm{MPa}(90 \% \mathrm{UF}+10 \%$ tannin). They used a pressure of $2.95 \mathrm{MPa}$ and a temperature of $170{ }^{\circ} \mathrm{C}$ with particle moisture of $16 \%$. For the present study the MOR for the $100 \% \mathrm{UF}$ adhesive was $7.35 \mathrm{MPa}\left(120^{\circ} \mathrm{C}\right)$, this value being $54.32 \%$ smaller than that found by the cited authors. For the adhesive $90 \%$ UF $+10 \%$ tannin, the same authors obtained a result $35.09 \%$ higher than the present study.

For both properties (MOR and MOE), the 100\% UF adhesive and $100 \% \mathrm{PF}$ at $120{ }^{\circ} \mathrm{C}$ showed the best results. This can be explained by the fact that the particles used in the production of agglomerated panels presented acid $\mathrm{pH}$ (4.86), facilitating the curing of the urea-formaldehyde resin that occurs in the same $\mathrm{pH}$ range. In the panels with addition of tannin $(20 \%)$ the properties were impaired, at both temperatures.

The uncontrolled presence of bark in the particles contributed to the static bending values not reaching CS 236-66 (1968), being respectively 10.98 MPa and 12.35 MPa for MOR (UF and FF) and 2,401 MPa and 1,715 MPa for MOE (UF and FF). Nemli, Gezer, Yildiz, Temiz and Aydin (2006), when evaluating the mechanical properties of agglomerated panels produced with Alnus glutinosa wood impregnated with Pinus brutia bark extract, concluded that larger bark quantities promoted reduced modulus of rupture and elasticity; however, for those panels manufactured with $1 \%$ of bark of Pinus brutia the minimum requirements of standard CS 236-66 (CS, 1968) for MOR were met.

The influence of particle size distribution on the production of agglomerated panels of Pinus taeda was studied by Peixoto and Brito (2000), who observed that the best results for MOR and MOE were obtained with adhesive based on urea-formaldehyde and with particles of smaller dimensions. These results are similar to those found in the present study that showed better averages in the ureaformaldehyde adhesive for both MOR and MOE. The size and shape of the particles in agglomerated panels influence the physical and mechanical properties (Li, Cai, Winandy, \& Basta, 2010).

The mean values of internal bonding ranged from 0.26 $\mathrm{MPa}$ to $2.11 \mathrm{MPa}$, highlighting the $100 \% \mathrm{UF}$ adhesive at $120{ }^{\circ} \mathrm{C}$ (Table 5). All the tested conditions complied with the minimum required - 0.42 $\mathrm{MPa}$ (CS, 1968), except for the use of $20 \%$ of tannin with PF at both temperatures. Teodoro (2008) found internal bonding values higher than the standard even when tannin was added in the PF adhesive composition. However, in this work, the increase of tannin in the commercial adhesives provided a reduction of this property. Melo et al. (2010b) also found lower values than this study.

TABLE 5. Mean internal bonding values for tested adhesives and temperatures.

\begin{tabular}{ccc}
\hline & \multicolumn{3}{c}{ Internal Bonding $(\mathrm{MPa})$} \\
\cline { 2 - 3 } Adhesive & \multicolumn{3}{c}{ Temperature $\left.{ }^{\circ} \mathrm{C}\right)$} \\
\cline { 2 - 3 } & $2.11(0.43) \mathrm{aA}$ & $0.69(0.14) \mathrm{bB}$ \\
UF 100\% & $1.86(0.25) \mathrm{aB}$ & $1.28(0.23) \mathrm{bA}$ \\
PF 100\% & $0.85(0.22) \mathrm{aD}$ & $0.53(0.26) \mathrm{bBC}$ \\
TF 100\% & $1.58(20.89) \mathrm{aC}$ & $1.43(0.26) \mathrm{bA}$ \\
TUF 90:10 & $1.59(31.45) \mathrm{aC}$ & $0.52(0.29) \mathrm{bBC}$ \\
TUF 80:20 & $0.98(21.3) \mathrm{bD}$ & $1.51(0.18) \mathrm{aA}$ \\
TPF 90:10 & $0.26(0.09) \mathrm{aE}$ & $0.36(0.09) \mathrm{aE}$ \\
TPF 80:20 & &
\end{tabular}

* Means followed by lower case letter, vertically, and upper case, horizontally, do not differ statistically ( $\mathrm{P} \leq \mathrm{O} .05)$ by the Tukey test. Value in parentheses is the standard deviation. 
The use of processed edgings with conventional particles in panels with $50 \%$ conventional particle mixed with $50 \%$ of edgings glued with $6 \%$ of urea-formaldehyde adhesive showed better results - $0.459 \mathrm{MPa}$, than those found in a study by Brito, Sampaio, Oliveira and Batista (2006). Hillig, Haselein and Santini (2002) found results similar to those for wood panels of the same species and density, with mean values between $0.185 \mathrm{MPa}$ and $0.286 \mathrm{MPa}$. Similar results were found in the present study.

The mechanical strength of the panels can be compromised if the adhesive distribution is not adequate, which in turn is also associated with the shape of the particles. Therefore, since the particles used were not produced for this purpose, the quality of the panels was impaired. In this sense, by using a composition with virgin particles and a particle size control (mainly thickness), a better mechanical performance of the panels could have been achieved.

Mean values of screw withdrawal at the surface ranged from $283.83 \mathrm{~N}$ to $795.33 \mathrm{~N}$ (Table 6). The value required by the ANSI A-208.1 (American National Standards Institute [ANSI], 1999) for this property is $400 \mathrm{~N}$; only the 80:20 TPF adhesive at $120^{\circ} \mathrm{C}$ did not reach the established. In general, this result is very important for the manufacture of furniture, since screws are used to join the pieces.

Tinti, Gonçalves, Batista, and Vidaurre (2012), who performed screw withdrawal on the Oriented Strand Board (OSB) panel surface at the edge and center, found 1857.10 $\mathrm{N}$ and $1676.95 \mathrm{~N}$, respectively. These values are higher than the ones found in the present study, corresponding to an OSB panel classified as medium density, of structural character with the particles following a specific index of slenderness, unlike this work.

For screw withdrawal at the top, mean values ranged from $225.83 \mathrm{~N}$ to $1034.8 \mathrm{~N}$. According to NBR 14810-2 (ABNT, 2006), the minimum value for this property is 800 $\mathrm{N}$. Some panels did not produce a satisfactory result in accordance with this standard, except UF $100 \%\left(120^{\circ} \mathrm{C}\right)$; $100 \%$ PF $\left(120^{\circ} \mathrm{C}\right.$ and $\left.140{ }^{\circ} \mathrm{C}\right)$; TUF $90: 10\left(140{ }^{\circ} \mathrm{C}\right)$ and TPF 90:10 $\left(140^{\circ} \mathrm{C}\right)$.

TABLE 6. Mean screw withdrawal values at the surface and top of panels produced for tested adhesives and temperatures.

\begin{tabular}{|c|c|c|c|c|}
\hline \multirow{3}{*}{ Adhesive } & \multicolumn{4}{|c|}{ Screw Withdrawal (N) } \\
\hline & \multicolumn{2}{|c|}{ Surface } & \multicolumn{2}{|c|}{ Top } \\
\hline & $120\left({ }^{\circ} \mathrm{C}\right)$ & $140\left({ }^{\circ} \mathrm{C}\right)$ & $120\left({ }^{\circ} \mathrm{C}\right)$ & $140\left({ }^{\circ} \mathrm{C}\right)$ \\
\hline UF 100\% & $795.33 a A^{*} B^{*}(61.5)$ & $\begin{array}{c}494.83 \mathrm{bC} \\
(88.5)\end{array}$ & $\begin{array}{c}1034.80 \text { aA } \\
(124.9)\end{array}$ & $\begin{array}{c}362.00 \mathrm{bC} \\
(95.5)\end{array}$ \\
\hline PF 100\% & $\begin{array}{c}873.00 \mathrm{aA} \\
(53.9)\end{array}$ & $\begin{array}{c}722.17 \mathrm{bAB} \\
\text { (83.0) }\end{array}$ & $\begin{array}{c}1050.70 \text { aA } \\
(146.6)\end{array}$ & $\begin{array}{c}878.83 \text { aA } \\
(152.4)\end{array}$ \\
\hline TF $100 \%$ & 595.83 aCD (134.4) & $\begin{array}{c}501.83 \mathrm{aC} \\
(103.3)\end{array}$ & $\begin{array}{c}535.17 \mathrm{aBC} \\
(271.5)\end{array}$ & $\begin{array}{c}350.17 \mathrm{aC} \\
(148.6)\end{array}$ \\
\hline TUF 90:10 & $\begin{array}{c}663.33 \mathrm{aBCD} \\
\text { (112.0) }\end{array}$ & $\begin{array}{c}647.67 \text { aABC } \\
(86.6)\end{array}$ & $\begin{array}{c}739.17 \text { aAB } \\
(274.9)\end{array}$ & $\begin{array}{c}808.50 \mathrm{aAB} \\
(112.4)\end{array}$ \\
\hline TUF 80:20 & $\begin{array}{c}748.33 \text { aABC } \\
\text { (119.10) }\end{array}$ & $\begin{array}{c}581.83 \mathrm{bBC} \\
(190.9)\end{array}$ & $\begin{array}{c}652.50 \mathrm{aB} \\
(398.4)\end{array}$ & $\begin{array}{c}493.17 \mathrm{aBC} \\
(164.9)\end{array}$ \\
\hline TPF 90:10 & $\begin{array}{c}555.33 \mathrm{bD} \\
(64.4)\end{array}$ & $\begin{array}{c}761.00 \mathrm{bD} \\
(84.4)\end{array}$ & $\begin{array}{c}456.33 \mathrm{aBC} \\
(162.5)\end{array}$ & $\begin{array}{c}927.50 \mathrm{aA} \\
(97.2)\end{array}$ \\
\hline TPF 80:20 & $\begin{array}{c}283.83 \mathrm{bE} \\
(31.1)\end{array}$ & $\begin{array}{c}490.67 \mathrm{aC} \\
(54.2)\end{array}$ & $\begin{array}{c}225.83 \mathrm{aC} \\
(31.6)\end{array}$ & $\begin{array}{c}427.83 \mathrm{aC} \\
(94.6)\end{array}$ \\
\hline
\end{tabular}

* Means followed by lowercase letter, vertically, and uppercase letter, horizontally (for the respective property), do not differ statistically ( $p \leq 0.05$ ) by the Tukey test. Value in parentheses corresponds to the coefficient of variation. 
Some possible explanations for the screw removal at the top not being satisfactory, could be due to its particle size, since these do not have an ideal slenderness index, i.e., close to 200 (Maloney, 1993). Also, the uncontrolled presence of bark in the particles, contributed negatively to the adhesion between the substrate and the adhesive impeding it to occur satisfactorily, making the panel with weak bonds between the particles in this sense.

The slenderness index is an important parameter and exerts influence on the characteristics of the panel because it is directly related to the contact area between wood particles and adhesive, influencing the mechanical properties of the adhesive (Iwakiri, Keinert Júnior, \& Mendes, 2005; Saldanha, 2004). Therefore, greater particle size control may provide improvements in mechanical performance on the panels.

Regarding the degradation by Postia placenta fungus, all the panels were classified as highly resistant (Fig. 1), except the $100 \%$ TF adhesive which presented moderate resistance, indicating that the TF adhesive has low fungalresistant chemical properties and requires more studies.

Regarding the fungus Trametes versicolor the 90:10 TFF adhesive was considered highly resistant; the $100 \% \mathrm{FF}$ and $100 \%$ TF adhesives were resistant and the UF 100\% adhesives; TUF 90:10; TUF 80:20 and TFF 80:20 were considered moderately resistant (Fig. 2), according to ASTM D-2017 (2005b).

Resistance to white rot fungus (Trametes versicolor) in agglomerated panels of Eucalyptus grandis wood particles bonded with urea-formaldehyde and tannin- formaldehyde showed no significant difference, but on average the panels produced with tannin-based adhesive were the least resistant (Melo et al., 2010a). This behavior is similar to that found in the present work, since the adhesives that lost more mass were the combinations of urea-formaldehyde with tannin (in proportions of $10 \%$ and $20 \%$ ).

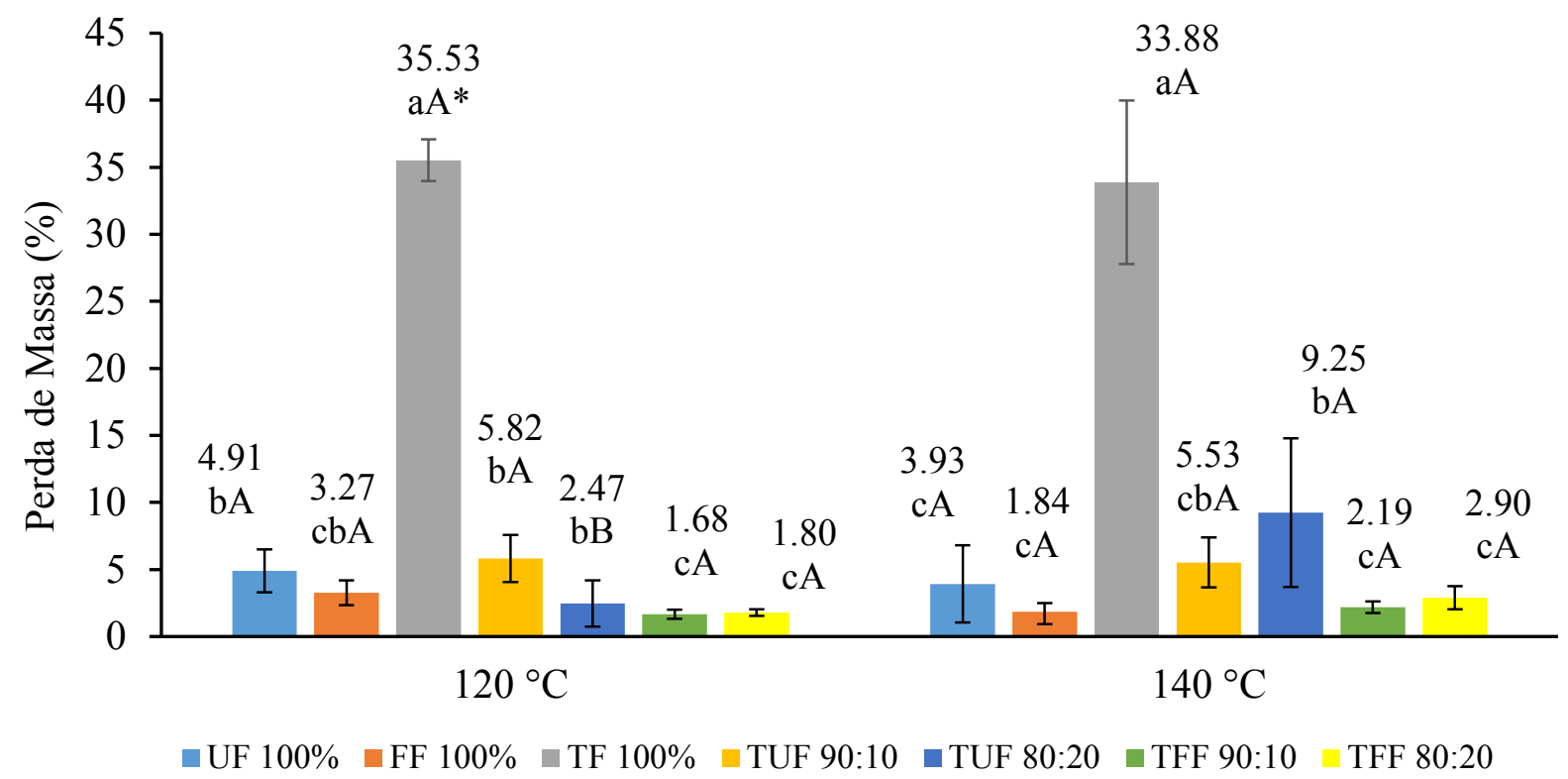

FIGURE 1. Mean values of mass loss of the agglomerated panels due to Postia placenta fungus in the tested adhesives and temperatures.

*Means followed by lowercase letter, at the same temperature, and upper case in the same color pattern, do not differ statistically ( $\mathrm{p} \leq \mathrm{0.05)}$ by the Tukey test. The bar is the standard deviation. 


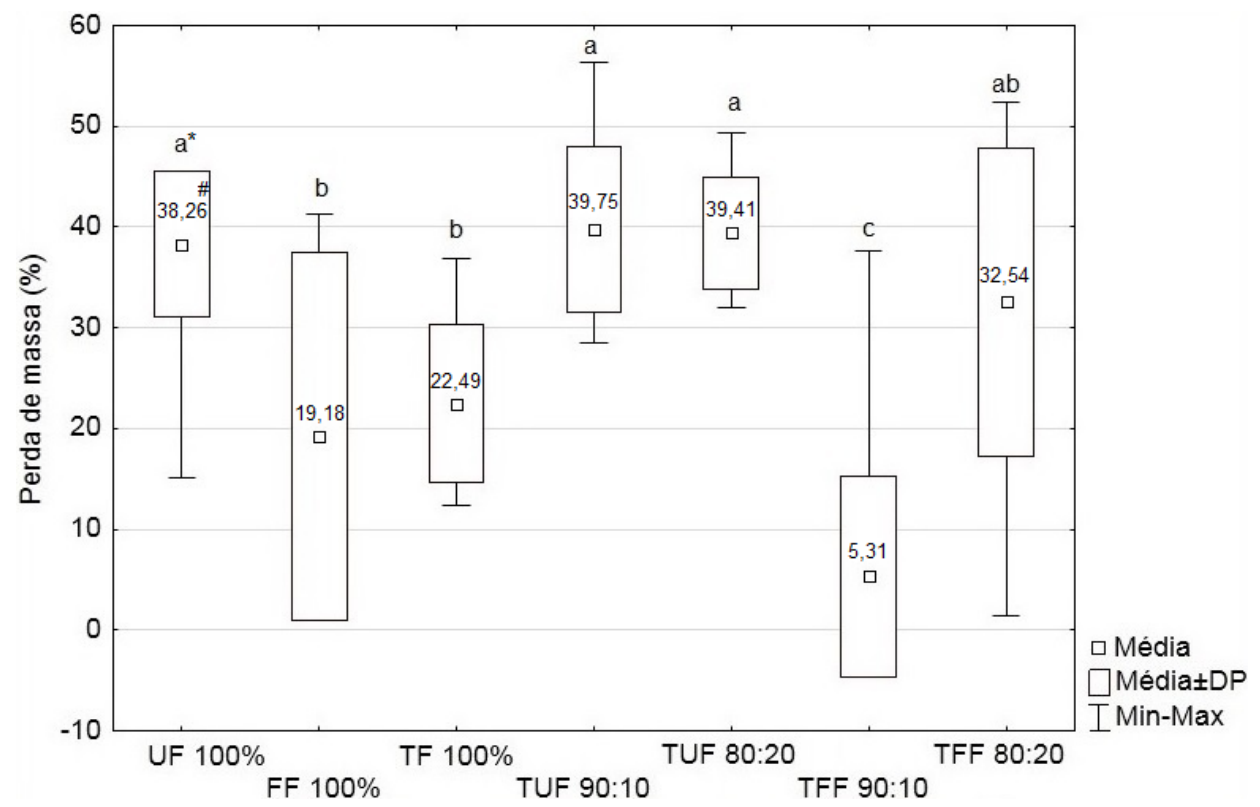

FIGURE 2. Mean values of mass loss of agglomerated panels due to Trametes versicolor fungus for each tested adhesive.

* Means followed by the same letter do not differ statistically ( $x \leq 0.05$ ) by the Tukey test. \# Mean mass loss value for each adhesive.

In agglomerated panels produced with acacia wood glued with urea-formaldehyde-based adhesive and proportions of tannins $(10,20$ and $30 \%)$ in the presence of all adhesives, the classification was mentioned as resistant to white rot fungus (Trametes versicolor) (Gonçalves, Brocco, Paes, Loiola, $\&$ Lelis, 2014). The same authors also observed that there is a tendency of improvement in the resistance of the panels with the increase of the compaction ratio, but unrelated to the increase of the proportion of tannins in the ureaformaldehyde.

\section{Resistance to Cryptotermes brevis termites}

After 45 days, a significant mortality rate of termites was observed in all treatments. Moi (1980), Kartal and Green III (2003) state that this may be associated with the presence of extractives, resins and ashes (silicates), mainly in the bark. In wood with higher ash contents, Paes, Medeiros Neto, Lima, Freitas, and Diniz (2013) found faster death of dry wood termites.

The adhesive that lost more mass was 80:20 TPF with $1.51 \%$ loss, and the one that lost less mass was the $100 \%$ PF with $0.16 \%$ (Fig. 3). Thus, the amount of tannin present in the adhesive contributed to a decrease in the resistance of the panel to the dry wood termite in the phenolformaldehyde adhesive.

For the UF, PF and TF (100\%) adhesives, with 20 days of testing, mortality reached $100 \%$; despite this, the $100 \%$ TF adhesive was the second most attacked, with $1.34 \%$ mass loss.

Ribeiro et al. (2014) evaluated commercial agglomerates of eucalyptus, eucalyptus + pinus and sugarcane bagasse on dry wood termite attack (Cryptotermes brevis), and found a greater loss of mass in the eucalyptus panels $(2.78 \%)$ and lower loss in the panel of sugarcane bagasse $(0.19 \%)$. The latter was less attacked due to chemical components present in sugarcane bagasse, since this residue may present mineral components, such as silica in large quantities, as observed by Belini, Tomazello Filho, Mendes, Leite and Lima (2012).

\section{CONCLUSIONS}

Proportions above $10 \%$ of tannin added to the phenolformaldehyde adhesive are not recommended as there are significant increases in viscosity, generating granules in the modified adhesive (TPF). 


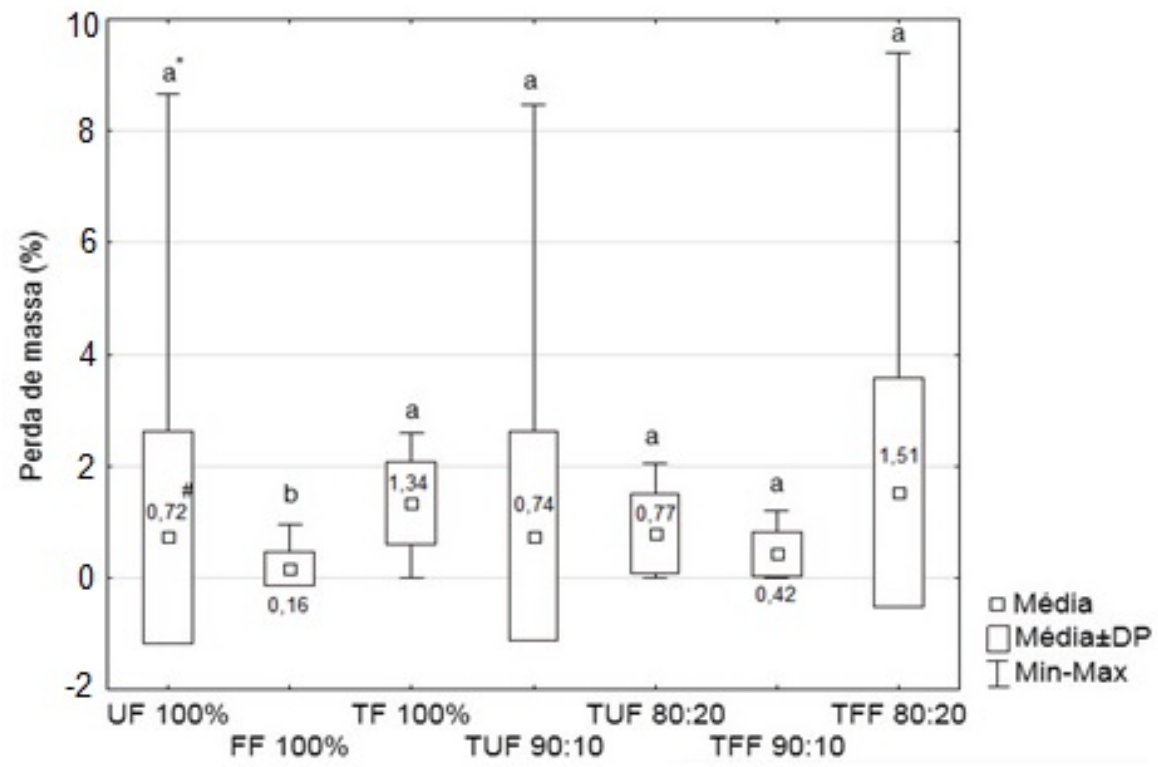

FIGURE 3. Mean values of mass loss of the agglomerated panels to the dry wood termite.

* Means followed by the same letter do not differ statistically ( $p>0.05$ ) by the Tukey test. \# Average mass loss value for each adhesive.

The addition of $20 \%$ of tannin in the phenol-formaldehyde adhesive yields negative results in several technological properties, diminished resistance to the attack of degrading fungi and for dry wood termites.

The Trametes versicolor fungus caused greater mass loss to the tested agglomerated panels when compared to Postia placenta.

\section{REFERENCES}

Albuquerque, C. E. C., Iwakiri, S., \& Keinert Junior, S. (2005). Adesão e adesivos. In S. Iwakiri, Painéis Reconstivídos de Madeira. Curitiba: Fupef.

American Society for Testing and Materials [ASTM] (2005a). ASTM D-1413: Standard test method for wood preservatives by laboratory soil-block cultures. Philadelphia.

American Society for Testing and Materials [ASTM] (2005b). ASTM D-2017: Standard method of accelerated laboratory test of natural decay resistance of woods. Philadelphia.

Associação Brasileira de Normas Técnicas [ABNT] (2003). NBR 11941: madeira - determinação da densidade básica. Rio de Janeiro.
Associação Brasileira de Normas Técnicas [ABNT] (2006). NBR 14810-2: chapas de madeira aglomerada - Requisitos. Rio de Janeiro.

Associação Brasileira de Normas Técnicas [ABNT] (2006). NBR 14810-3: Chapas de madeira aglomerada - Método de ensaio. Rio de Janeiro.

Belini, U. L., Tomazello Filho, M., Mendes, L. M., Leite, M. K. and Lima, P. M. R. (2012). Sand content in composites made with sugarcane bagasse and eucalypt. Floresta $e$ Ambiente, 19(2), 250-255. doi:10.4322/floram.2012.030

Brito, E. O., Sampaio, L. C., Oliveira, J. N. and Batista, D. C. (2006). Chapas de madeira aglomerada utilizando partículas oriundas de madeira maciça e de maravalhas. Scientia Forestalis, 1(72), 17-21.

Carneiro, A. C. O., Vital, B. R., Pimenta, A. S. and Della Lucia, R. M. (2004). Propriedade de chapas de flocos fabricadas com adesivo de ureia-formaldeído e de taninos de casca de Eucalyptus grandis W. Hill ex Maiden ou de Eucalyptus pellita F. Muell. Revista Arvore, 28(5), 715-724. doi:10.1590/S0100-67622004000500011

Commercial Standard [CS] (1968). CS 236-66: Mat formed wood particleboard. Geneva.

Gonçalves, F. G., Brocco, V. F., Paes, J. B., Loiola, P. L. and Lelis, R. C. C. (2014). Resistance of Acacia mangium Willd. wood 
particleboards bonded with urea-formaldehyde and tannins to wood-destroying organisms. Floresta e Ambiente, 21(3), 409-415. doi:10.1590/2179-8087.059113

Gonçalves, F. G., Lelis, R. C. C. and Oliveira, J. T. S. (2008). Influência da composição da resina tanino-uréiaformaldeído nas propriedades físicas e mecânicas de chapas aglomeradas. Revista Árvore, 32(4), 715-722. doi:10.1590/S0100-67622008000400013

Hillig, E., Haselein, C. R., \&Santini, E. J. (2002). Propriedades mecânicas de chapas aglomeradas estruturais fabricadas com madeira de Pinus, Eucalipto e Acácia-negra. Ciência Florestal, 12(1), 59-70.

Institute of Technological Research Wood Division - IPT (1980). DIMAD D-2: Ensaio acelerado da resistência natural ou de madeira preservada ao ataque de térmitas do gênero Cryptotermes (Fam. Kalotermitidae). São Paulo.

Iwakiri, S., Keinert Júnior, S., \& Mendes, L. M. (2005). Painéis de Madeira Aglomerada. In S. Iwakiri, Painéis de Madeira Reconstituida. Curitiba: Fupef.

Kartal, S. N., \& Green III, F. (2003). Decay and termite resistance of medium density fiberboard (MDF) made from different wood species. International Biodeterioration \& Biodegadation, 51(1), 29-35. doi:10.1016/S09648305(02)00072-0

Kollmann, F. F. P., Kuenzi, E. W., \& Stamm, A. J. (1975). Principles of wood science and technology: wood based materials. New York: Springer-Verlog.

Li, X., Cai, Z., Winandy, J. E., \& Basta, A. F. (2010). Selected properties of particleboard panels manufactured from rice straws of different geometries. Bioresource Technology, 101(12), 4662-4666. doi:10.1016/j.biortech.2010.01.053

Low, C. M. (1980). New laboratory method for testing the resistance of particleboards to the drywood termite Cryptotermes cynocephalus. Malaysian Forester, 43(3), 350355.

Maloney, T. M. (1993). Modern particleboard and dry-process fiberboard manufacturing. San Francisco: M. Freeman.

Maloney, T. M. (1996). The family of wood composite materials. Forest Products Journal, 46(2), 19-26.

Melo, R. R., Santini, E. J., Haseleim, C. R., Stangerlin, D. M., Muller, M. T., \& Del Menezzi, C. H. S. (2010b). Physicalmechanical properties evaluation of the Eucalyptus grandis particleboard glued with urea-formaldehyde and tanninformaldehyde. Floresta, 40(3), 497-506. doi:10.5380/rf.v40i3.18911
Melo, R. R., Santini, E. J., Paes, J. B., Garlet, A., Stangerlin, D. M., \& Del Menezzi, C. H. S. (2010a). Particleboard resistance to termite and fungi made with Eucalyptus grandis wood and different resins. Cerne, 16, 82-89 (Suplemento).

Nemli, G., Gezer, E. D., Yildiz, S., Temiz, A., \& Aydin, A. (2006). Evaluation of the mechanical, physical properties and decay resistance of particleboard made from particles impregnated with Pinus brutia bark extractives. Bioresource Technology, 97(16), 2059-2064. doi:10.1016/j.biortech.2005.09.013

Paes, J. B., Medeiros Neto, P. N., Lima, C. R., Freitas, M. F., \& Diniz, C. E. F. (2013). Effects of extractives and ash on natural resistance of four woods to xylophogous termites. Cerne, 19(3), 399-405. doi:10.1590/S010477602013000300006

Paes, J. B., Santana, G. M., Azevedo, T. K. B., Morais, R. M., \& Calixto Júnior, J. T. (2010). Tannic substances present in several parts of Anadenanthera colubrina (Vell.) Brenan. var. cebil (Gris.) Alts.) tree. Scientia Forestalis, 38(87), 441447.

Peixoto, G. L., \& Brito, E. O. (2000). Pinus taeda particle size valuation mixed with commercial resin to particleboards manufacture. Floresta e Ambiente, 7, 60-67.

Pizzi, A. (1980). Tannin based adhesives. Journal of Macromolecular Science: Pure and Applied Chemistry, 18(2), 247-315.

Pizzi, A. (1994a). Advanced wood adhesives technology. New York: Marcel Dekker.

Pizzi, A. (1994b). Urea-formaldehyde adhesives. In A. Pizzi, \& K. Mittal, Handbook of Adhesive Technology. New York: Marcel Dekker.

Ribeiro, M. X., Bufalino, L., Mendes, L. M., Sá, V. A.; Santos, A., \& Tonoli, G. H. D. (2014). Resistance of pine, australian red cedar woods and their derivate products to Cryptotermes brevis attack. Cerne, 20(3), 433-439. doi:10.1590/0104776020142003

Saldanha, L. K. (2004). Alternativas tecnológicas para produção de chapas de partículas orientadas "OSB". [Maestria]. Univeridade Federal do Paraná. Curitiba, PR, Brasil.

Silva, F. A. Z., \& Azevedo, C. A. V. (2016). The Assistat Software Version 7.7 and its use in the analysis of experimental data. African Journal Agricultural Research, 11(39), 3733-3740. doi:10.5897/AJAR2016.11522

Standards Institute American National. (1999). ANSI A208.1: Particleboard. Washington. 
Teodoro, A. S. (2008). Utilization of tannin adhesive in the production of particleboards and OSB. [Maestria]. Universidade Federal Rural do Rio de Janeiro. Seropédica, RJ, Brasil.

Tinti, V. P., Gonçalves, F. G., Batista, D.C., \& Vidaurre, G. B. (2012). Características tecnológicas de um painel comercial de partículas orientadas. Anais do XIII Encontro Brasileiro em Madeiras e em Estruturas de Madeira. CD-ROM. Vitória, Espírito Santo: UFES.
Received: 30 May 2017

Accepted: 25 March 2018

Published: 18 December 2018

This paper must be cited as:

Tinti, V. P., Gonçalves, F. G., Paes, J. B., Arantes, M. D. C., \& Vieira, M. C. (2018). Mechanical properties and resistance to fungi and termite in particleboard of eucalyptus. Madera y Bosques, 24(3), e2431578.doi: 10.21829/myb.2018.2431578

Madera y Bosques by Instituto de Ecología, A.C. is distributed under a Creative Commons Licence Attribution-NonCommercial-ShareAlike 4.0 Internacional. 